\title{
PCM1/JAK2 Fusion Protein
}

National Cancer Institute

\section{Source}

National Cancer Institute. PCM1/JAK2 Fusion Protein. NCI Thesaurus. Code C129856.

A fusion protein that is encoded by the PCM1/JAK2 fusion gene. This protein contains the predicted coiled-coil domains and the ATP/GTP binding domain from pericentriolar material 1 protein and the entire tyrosine kinase domain of the tyrosine-protein kinase JAK2 protein. 